Scientific Journal Warsaw University of Life Sciences - SGGW

Problems of World Agriculture volume 18 (XXXIII), number 4, 2018: 236-249

DOI: 10.22630/PRS.2018.18.4.114

Marzena Kacprzak $^{1}$, Agnieszka Król ${ }^{2}$, Marta Radziszewska ${ }^{3}$

${ }^{1}$ Warsaw University of Life Sciences - SGGW, Poland,

${ }^{2}$ Warsaw Management University, Poland

${ }^{3}$ Civil Aviation Authority, Warsaw, Poland

\title{
European Integration Influence on the Development of Human Capital of Small and Medium Enterprises in Poland
}

\begin{abstract}
Enterprises from the SME sector significantly affect the quality of human capital in Poland and the standards of their management are rising every year. The aim of this article is to present the essence and specifics of human capital of SMEs, showing the impact of European integration on the development of human capital in this sector. In addition, the authors focus on finding the answer to the question whether employers willingly reach for EU funding (sources of knowledge, forms, types of funding, barriers to access to funds) to be able to support and develop human capital that they have in the long run. The study was carried out by a survey method. The analysis made allowed to formulate the following conclusions. Entrepreneurs willingly undertake to raise funds from EU funds. Respondents were convinced that EU funds help in the development of their businesses, although obtaining funding alone is not easy. The respondents pointed to barriers, which include complicated and lengthy procedures, as well as low availability of information.
\end{abstract}

Key words: human capital, small and medium enterprises, European integration, EU assistance programs, EU funds

JEL Classification: F15, J24, 015

\section{Introduction}

Small and medium enterprises are very important elements of Polish economy. The sector of small and medium-sized enterprises is of broad interest due to its specificity. These companies have to take into account many difficulties in terms of functioning on the market. The survival of a company on the market depends, inter alia, on the level of innovation, development opportunities as well as the possibility of using external assistance. A small and medium enterprise sector is an important element of the Polish and European economy. The development of the SME sector determines the competitiveness of individual economies and has a real impact on the economic conditions of the country. The share of small and medium-sized entities is significant in job creation (Danielak, Mierzwa, Bartczak, 2017). MSP represent $99.8 \%$ of all companies operating on the market within the whole European Community. The European Union appreciates the importance of small and medium-sized enterprises. It strives to support their development and strengthen competitiveness on the market (Kamińska, 2010). The Ministry of State Treasury is of great

${ }^{1} \mathrm{PhD}$, Department of European Policy and Marketing WULS-SGGW, ul. Nowoursynowska 166,

02-787 Warszawa, e-mail: marzena_kacprzak@sggw.pl, https://orcid.org/0000-0002-0680-8241

${ }^{2} \mathrm{PhD}$, Warsaw Management University, ul. Kawęczyńska 36, 03-772 Warszawa, e-mail: krolagnieszka@op.pl, https://orcid.org/0000-0002-5685-7578

${ }^{3}$ MSc, Personnel Licensing Department, Civil Aviation Authority, ul. M. Flisa 2, 02-247 Warszawa,

e-mail: m.radziszewska@onet.pl 
importance to both the Polish economy and the European economy, which is why they were included at the Community level and at the level of regions and local authorities (Mirończuk, 2012). An expression of this special protection from the European Union are assistance programs addressed to enterprises from the SME sector (Kamińska, 2010).

The European Community is not indifferent to the potential of SMEs and implements a number of activities aimed at strengthening the role of this sector in the market. Its policy concentrates on 10 directions included in the European Charter for Small Enterprises: entrepreneurship education and training, lower costs and faster start-up, more efficient legislation and better regulations, availability of skills, improved on-line access, wider activities beyond the single market, taxation and financial issues, increasing the technological capabilities of small enterprises, effective e-commerce models and the best support for small enterprises, developing a stronger and more effective representation of small businesses interests at the level of the European Union and individual countries (Lewandowska, 2016).

The research problem of the paper is the attempt to determine if SMEs entrepreneurs use resources from European Union to develop human capital.

\section{Literature review}

In the literature, many different definitions of human capital can be encountered, dealing with issues both in a broader and narrower context. The review of definitions by various authors inclines the following reflections - human capital includes elements of personality; human qualities and abilities, such as intellectual dexterity, intelligence, energy, analytical skills, synthesis or just common sense and flexibility of mind (Król, 2016). Addressing need of this article, the definition is defined as "all of the specific characteristics and characteristics embodied in employees (knowledge, skills, abilities, health, motivation) that have a definite value and are a source of future income for both the employee-owner of the human capital and the organization benefiting from this capital on certain conditions" (Król, Ludwiczyński, 2008).

Human capital in SMEs due to the limited resources available to these enterprises is a strategic factor for them. In a globalized world, turbulent environment and growing competition, the competences of employees, their creativity, innovation, entrepreneurship and flexibility often mean "to be or not to be" for them. However, when it comes to human capital in SMEs, employers are also not easy. In principle, it can be said that they face serious obstacles at every stage of the implementation of human resources management processes. The specificity of HRM in SME differs significantly from what the implementation of the personnel function in large enterprises looks like. The owneremployer plays a key and dominant role in SMEs, which has a significant impact on the majority of decisions made in the company. On the other hand, employees usually have a wide range of duties and tasks, and at the same time quite limited career planning opportunities due to the simple structure of the company, including a limited number of jobs. The personnel function in the SME is also quite "simplified". Usually, individual people deal with employee issues, not whole departments, departments or divisions like in large corporations. Employers in SMEs also have limited HR tools. However, nothing is impossible and we hear more and more often about successful small businesses, often family ones. The proof of this may be the result of the contest organized by the Institute of Labor and Social Studies "Leader in Human Resources Management", where Sapphire 
Statuette and the title of ZZL Leader and Sapphire Laurel for three times the winner of the title of ZZL Leader for small and medium companies (e.g. Lódź Center for Teachers' Training and Practical Education 2016) ${ }^{4}$.

As the results of research conducted by the Polish Agency for Enterprise Development show, there are a number of small and medium-sized enterprises implementing good practices in the area of human capital management in spite of many barriers and limitations. For example, AQUAINVEST sp. z o.o. Construction industry focuses its activities on measuring human capital based on a systematic assessment of employee competencies and work performance, which significantly reduces the employee rotation rate and streamlines the project management process (Measure the most difficult measurable, 2015). Another small enterprise in the production and distribution of mineral water PiastPol Klejnowski Kobierecki sp. J. Employing about 30 employees significantly improved their competitiveness by modifying their human resources management policies by noticing the nature and importance of conducting a dialogue with employees. In its activities, the focus was on cyclical staff survey (additional questions are introduced each year), improvement of the communication system in the company (systematic meetings, interviews with employees, development of IT infrastructure, appreciation of employees' opinions and observation) and analysis of employee competencies based on periodic reports of department heads (employees' fulfillment of duties, performance of their work, board observations, direct conversations with team members) (Measure the most difficult measurable, 2015).

The key features that determine the effectiveness of the human capital management process in the SME sector can be considered the flexibility of the company, its focus on investing in the development of employees as strategic capital. The mentioned flexibility comes down to various areas of the company's operations, including in the area of HR, the flexibility of forms of employment and working time, forms of work organization, and the variability of the scope of tasks duties (Juchnowicz, 2013).

Trends in the global economy require established companies to become more and more entrepreneurial in order to handle uncertainty and environmental dynamism (Schmelter, Maure, Börsh, Brettel, 2012)

The enterprise's flexibility based on the constant search for development opportunities and implementation of changes taking place in the environment as factors that perfectly support this process favours the creativity and innovation among employees, and greater flexibility of their activities. The flexibility of human capital in SMEs (increasing the importance of competence and knowledge) must also be based on the use of specific tools in the area of not only development but also motivating employees, or building their involvement, among others through employee participation. The foundation of SME can become an organizational culture, a climate prevailing in the enterprise, an atmosphere, cultivated values, interpersonal relations, interpersonal bonds, mutual respect or empathy.

Human capital management in SMEs can be used to identify both the strengths and weaknesses of this complex process as well as opportunities and threats, as detailed in Table 1.

${ }^{4}$ Human Resources Management Leader Competition, https://www.ipiss.com.pl/konkurs-lider [access on 12/09/2018]. 
Table 1. Human capital management of SMEs in Poland - SWOT analysis

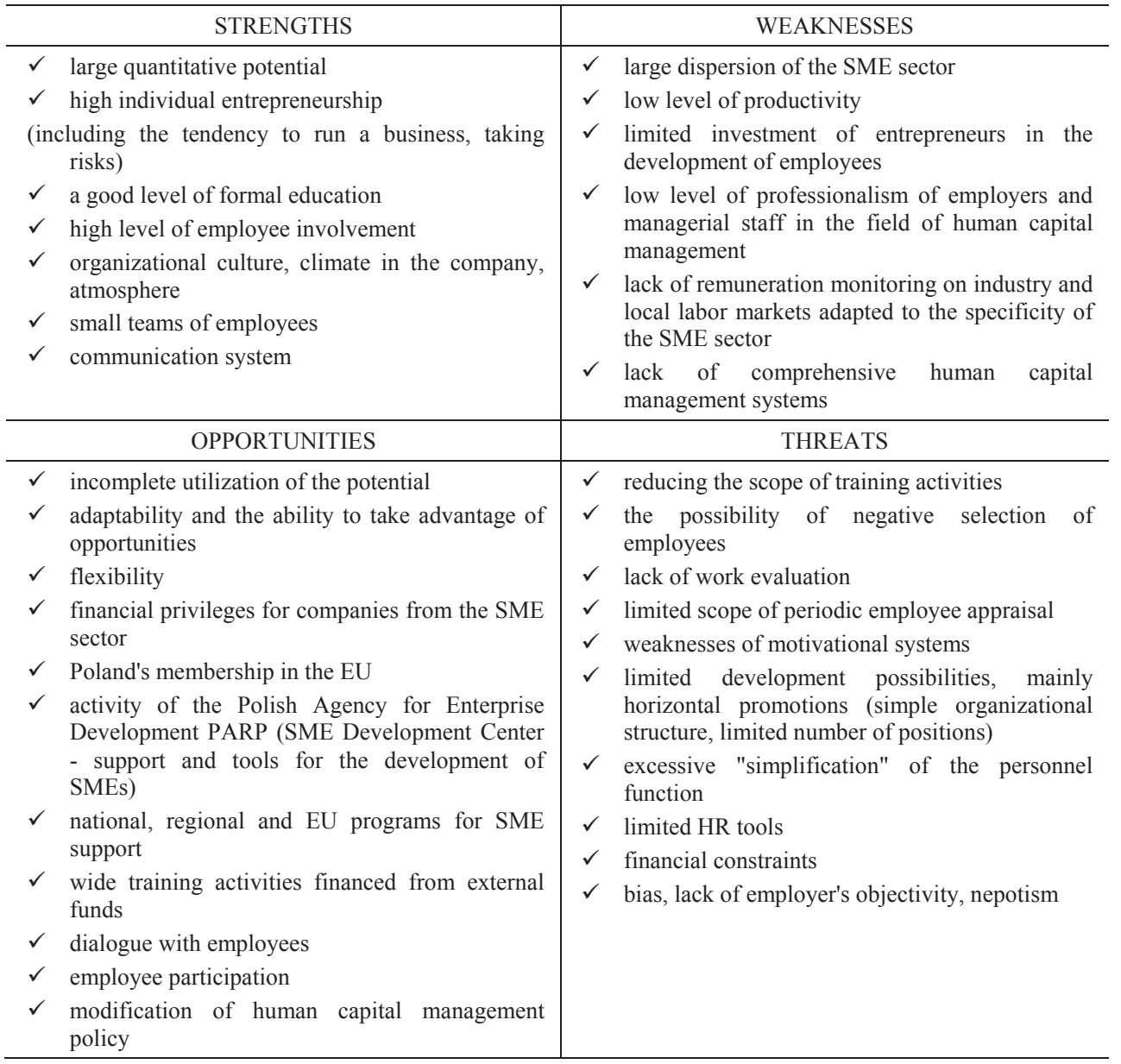

Source: own study based on M. Juchnowicz (2013). Care for employee satisfaction - a new paradigm or a new pragmatism?, Human Resource Management (3-4) 2013, IPiSS, Warsaw, p. 4.

However, a continuous need to shape and develop human capital in SMEs should be considered strategic. The study has shown that the two major reasons blocking innovation are seen to be lack of money and lack of time. The measurements for innovation success are quite equally evaluated being financial growth, followed by better market position and business growth (Kaufmann, Tsangar, Vrontis, 2012). The situation was considerably improved by Poland's accession to the EU and the related increased access to financial resources for the development of human capital of Polish enterprises. The situation of employees in the SME sector is improving every year. Among employers, you can also notice a change in awareness and approach to the desire to make the most of your employees' potential. Thanks to EU funds, including for example the Human Capital Operational Program, employees have increased opportunities to activate their knowledge, develop and acquire skills, shape competences and attitudes that help them find themselves and function efficiently in a turbulent environment. 


\section{Research methodology}

The aim of empirical research was to present and deepen the subject of small and medium-sized enterprises in the context of the consequences of Poland's presence in the European Union. The research was carried out by means of a survey method and it was of a pilot nature. Random selection was used. The research area is in Żyrardów and around. The following methods of quantitative data analysis were used to analyse the conducted research:

- differences between the compared groups were assessed on the basis of the significance test for qualitative (categorizable) variables - chi-square statistics;

- the Pearson correlation coefficient was also applied (based on chi-square values measure of dependencies between categorized variables, it indicates the strength of the relationship).

- statistically significant results were accepted that met the $\mathrm{p}$ condition below 0.05 .

The group of respondents was 100 people. They were owners and employees of small and medium-sized enterprises. The age structure of the respondents was as follows: less than 25 years $7 \%, 25-35$ years $33 \%, 36-40$ years $37 \%, 41-50$ years $14 \%$, over 50 years $9 \%$. The majority of the respondents had a Master's Degree $76 \%$, while the remaining incomplete higher $7 \%$, medium $3 \%$, and vocational $14 \%$.

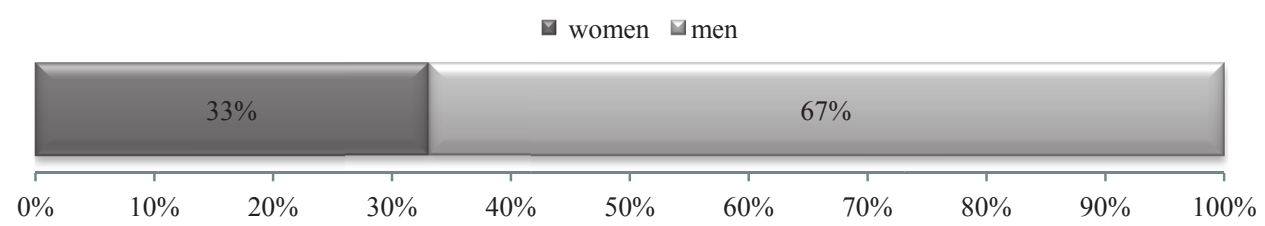

Fig. 1. Structure of respondents by gender

Source: own study.

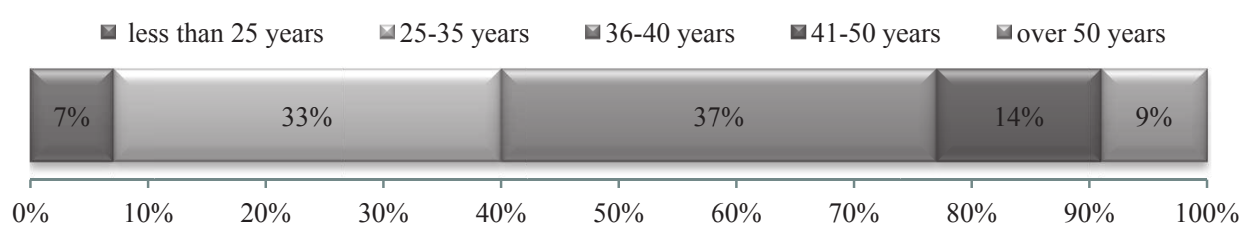

Fig. 2. Structure of respondents due to their age

Source: own study.

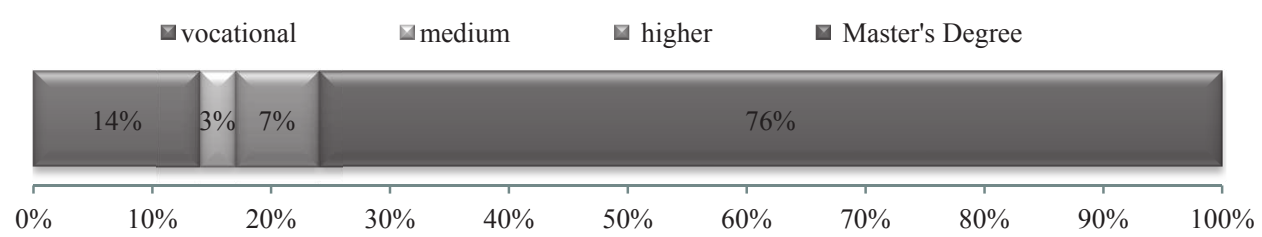

Fig. 3. Structure of respondents due to the level of education

Source: own study. 
In the own research, most companies were located in urban centres (94\%) rather than in rural areas (6\%). Three-quarters of enterprises functioned in cities with a population of $20-50$ thousand. (45\%) and 50-100 thousand (28\%). The size of the companies in which the respondents worked was varied. They employed up to 10 people $(23 \%), 10-49$ people (35\%), 50-249 people (36\%), more than 249 people $(6 \%)$. Half of the enterprises had been on the market for at least 10 years $(46 \%)$, while the remaining ones $(54 \%)$ were shorter than 10 years: $5-10$ years $22 \%, 1-5$ years $23 \%$, less than 1 year $9 \%$. The companies most often carried out service activities (36\%), but also production and service (20\%), production $(20 \%)$, commercial $(16 \%)$, another $(8 \%)$ - construction and commercial and service. Service and commercial activities are also dominant in the nationwide structure of SMEs: services $(50 \%)$, trade $(27 \%)$, construction $(13 \%)$, industry $(10 \%)$.

\section{Results of empirical tests}

In own research, $94 \%$ of the group confirmed that their company benefited from EU funding. The support of EU funds was significantly more often obtained by companies located in cities than in rural areas, employing more than 10 people, operating on the market for more than one year. It was received that the share of EU finances was the lowest in the group of service enterprises. Respondents indicated that their companies most often benefited from co-financing in the form of an EU subsidy of $68 \%$, followed by a $27 \% \mathrm{EU}$ loan and a $27 \%$ technology loan. It was found that in smaller enterprises EU funds were more often obtained in the form of loans, when in large companies and longer operating on the market, they were used more often from subsidies and technological credits.

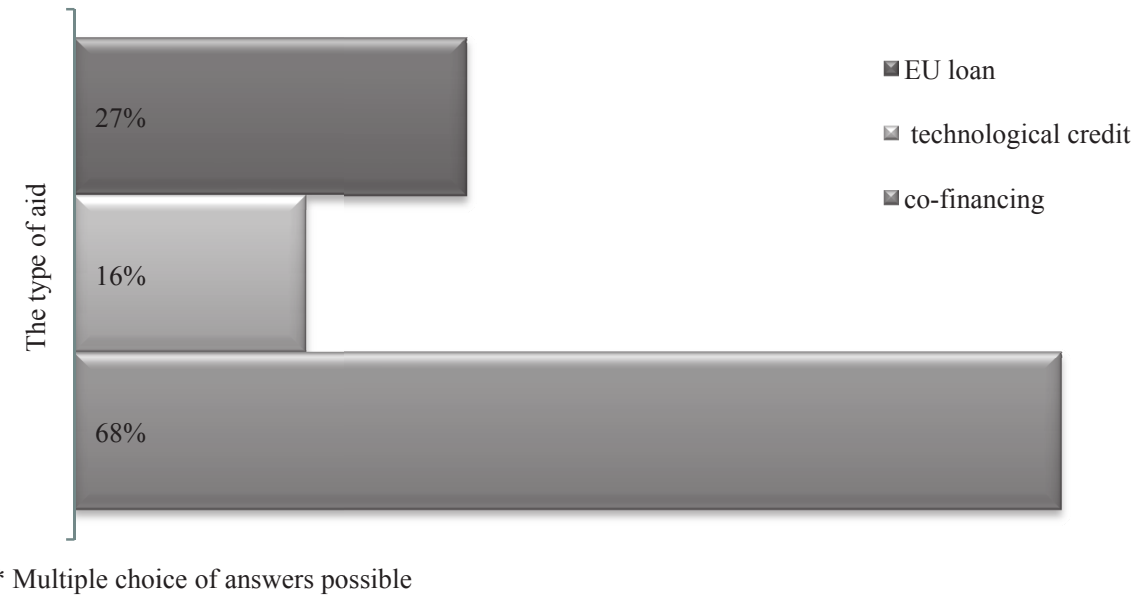

Fig. 4. Type of EU aid used by the company

Source: own study.

The respondents indicated that their companies most often used the EU Programs in the financial perspective 2014-2020 (40\%), EIP (38\%), CIP (35\%), Phare (20\%), RPO $(20 \%)$ and others $(5 \%)$ ): COSME, Business Support Program 5\%. 


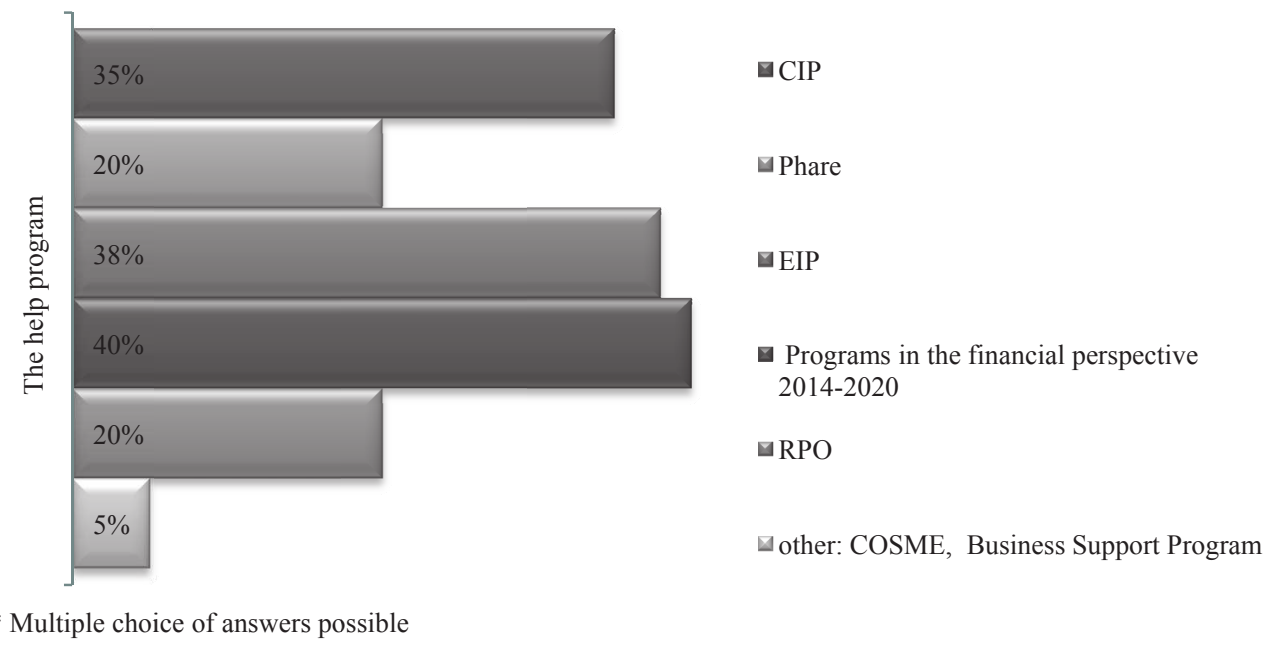

Fig. 5. The help program used by the company

Source: own study.

As indicated by Lewandowska and other authors (2016), an extensive system of EU programs addressed to the SME sector allows for a broad and fully synthetic support policy. The author confirms that Polish enterprises are struggling with similar problems as other European Union countries, the only difference is the size of certain difficulties. the need to stimulate domestic companies to implement an expansive policy, focused on overcoming individual development barriers and improving innovation, using EU funds. On the other hand, the fragmentation of programs causes problems in accessing information on subsidies, and the existing system of consulting services for SMEs, the information system still leaves much to be improved. All the more so because, as shown by the support of consulting companies, they reach bigger and stronger, and small businesses look for information on their own, often discouraging subsidies from the very beginning (Lewandowska, 2016).

The respondents indicated that their company was acquiring information on the availability of EU funds from the Internet $57 \%, 48 \%$ training, $41 \%$ information points, $40 \%$ television, $29 \%$ external consultancy, $22 \%$ conference, $12 \%$ radio, and other: leaflets / press $10 \%$ (Fig. 6.) It was found that in companies located in smaller towns: villages and towns up to 50,000. inhabitants were more often acquainted with EU funds on the radio, when companies from larger urban centres considerably more often used dedicated conferences (Tab. 2). It was also received that knowledge in smaller companies was significantly more often obtained through information available on websites (Tab. 3). 


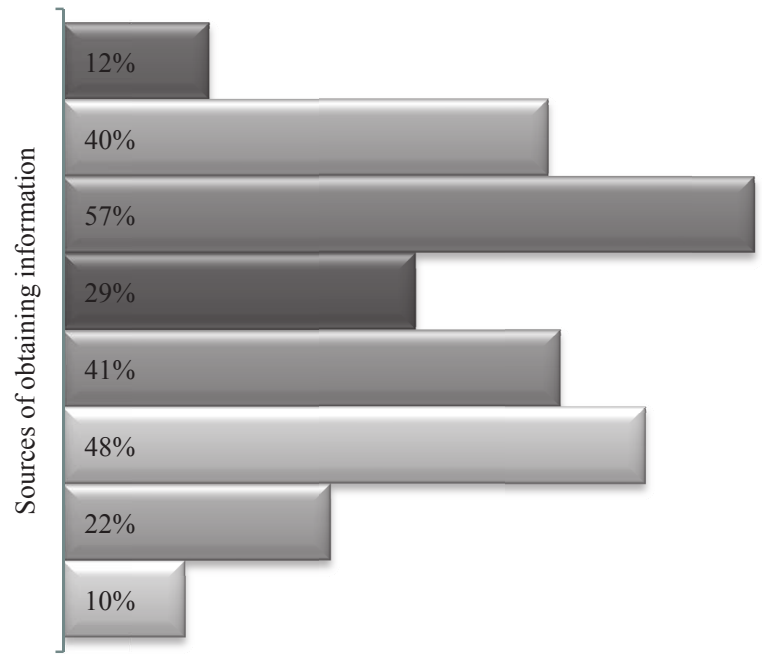
$\square$ radio
$\square$ television
$\square$ Websites
घ external consul-tancy
$\square$ information pairs
$\square$ training
$\square$ conferences
$\llbracket$ other: leaflet / press

* Multiple choice of answers possible

Fig. 6. Sources of obtaining information on the availability of EU funds

Source: own study.

Table 2. Sources of knowledge acquisition and company location

\begin{tabular}{|c|c|c|c|c|c|c|c|}
\hline $\begin{array}{l}\text { Sources of } \\
\text { knowledge }\end{array}$ & Village & $\begin{array}{l}\text { City up to } \\
20,000\end{array}$ & $\begin{array}{c}\text { Town } \\
20-50 \\
\text { thousand }\end{array}$ & $\begin{array}{c}\text { Town } \\
50-100 \\
\text { thousand }\end{array}$ & $\begin{array}{c}\text { City } \\
100-200 \\
\text { thousand }\end{array}$ & $\begin{array}{c}\text { City of } \\
200,000\end{array}$ & $\mathrm{Chi}^{2}$ test \\
\hline \multirow{2}{*}{ Radio } & 2 & 1 & 9 & 0 & 0 & 0 & 0,2713 \\
\hline & $33,33 \%$ & $12,50 \%$ & $20,00 \%$ & $0,00 \%$ & $0,00 \%$ & $0,00 \%$ & $\mathrm{p}=0,006$ \\
\hline \multirow{2}{*}{ TV } & 4 & 1 & 20 & 11 & 3 & 1 & 0,0791 \\
\hline & $66,67 \%$ & $12,50 \%$ & $44,44 \%$ & $39,29 \%$ & $33,33 \%$ & $25,00 \%$ & $\mathrm{p}=0,434$ \\
\hline \multirow{2}{*}{ Websites } & 2 & 8 & 27 & 14 & 4 & 2 & 0,1054 \\
\hline & $33,33 \%$ & $100,00 \%$ & $60,00 \%$ & $50,00 \%$ & $44,44 \%$ & $50,00 \%$ & $\mathrm{p}=0,296$ \\
\hline \multirow{2}{*}{$\begin{array}{l}\text { External } \\
\text { consultancy }\end{array}$} & 0 & 4 & 8 & 11 & 3 & 3 & 0,2232 \\
\hline & $0,00 \%$ & $50,00 \%$ & $17,78 \%$ & $39,29 \%$ & $33,33 \%$ & $75,00 \%$ & $\mathrm{p}=0,026$ \\
\hline \multirow{2}{*}{$\begin{array}{l}\text { Information } \\
\text { pairs }\end{array}$} & 0 & 7 & 21 & 9 & 2 & 2 & 0,0671 \\
\hline & $0,00 \%$ & $87,50 \%$ & $46,67 \%$ & $32,14 \%$ & $22,22 \%$ & $50,00 \%$ & $\mathrm{p}=0,507$ \\
\hline \multirow{2}{*}{ Training } & 0 & 5 & 22 & 16 & 2 & 3 & 0,1063 \\
\hline & $0,00 \%$ & $62,50 \%$ & $48,89 \%$ & $57,14 \%$ & $22,22 \%$ & $75,00 \%$ & $\mathrm{p}=0,292$ \\
\hline \multirow{2}{*}{ Conferences } & 0 & 3 & 3 & 10 & 3 & 3 & 0,3037 \\
\hline & $0,00 \%$ & $37,50 \%$ & $6,67 \%$ & $35,71 \%$ & $33,33 \%$ & $75,00 \%$ & $\mathrm{p}=0,002$ \\
\hline \multirow{2}{*}{$\begin{array}{l}\text { Other: leaflet / } \\
\text { press }\end{array}$} & 1 & 1 & 3 & 2 & 2 & 1 & 0,0676 \\
\hline & $16,67 \%$ & $12,50 \%$ & $6,67 \%$ & $7,14 \%$ & $22,22 \%$ & $25,00 \%$ & $\mathrm{p}=0,504$ \\
\hline
\end{tabular}

Source: own study. 


\section{M. Kacprzak, A. Król, M. Radziszewska}

Table 3. Sources of knowledge acquisition and company size

\begin{tabular}{l|ccccc}
\hline Sources of knowledge & $<10$ people & $10-40$ people & $50-249$ people & $\begin{array}{c}\text { More than } 249 \\
\text { people }\end{array}$ & Chi $^{2}$ test \\
\hline \multirow{2}{*}{ Radio } & 2 & 5 & 5 & 0 & 0,002 \\
& $8,70 \%$ & $14,29 \%$ & $13,89 \%$ & $0,00 \%$ & $\mathrm{p}=0,999$ \\
TV & 10 & 15 & 14 & 1 & 0,0932 \\
& $43,48 \%$ & $42,86 \%$ & $38,89 \%$ & $16,67 \%$ & $\mathrm{p}=0,356$ \\
Websites & 16 & 21 & 19 & 1 & 0,2133 \\
& $69,57 \%$ & $60,00 \%$ & $52,78 \%$ & $16,67 \%$ & $\mathrm{p}=0,033$ \\
External consultancy & 1 & 7 & 16 & 5 & 0,4465 \\
Information & $4,35 \%$ & $20,00 \%$ & $44,44 \%$ & $83,33 \%$ & $\mathrm{p}=0,000$ \\
Information pairs & 6 & 18 & 14 & 3 & 0,0870 \\
Training & $26,09 \%$ & $51,43 \%$ & $38,89 \%$ & $50,00 \%$ & $\mathrm{p}=0,389$ \\
& 3 & 15 & 26 & 4 & 0,4341 \\
Conferences & $13,04 \%$ & $42,86 \%$ & $72,22 \%$ & $66,67 \%$ & $\mathrm{p}=0,000$ \\
& 0 & 2 & 16 & 4 & 0,5098 \\
Other: leaflet / press & $0,00 \%$ & $5,71 \%$ & $44,44 \%$ & $66,67 \%$ & $\mathrm{p}=0,000$ \\
& $13,04 \%$ & $17,14 \%$ & $2,78 \%$ & $0,00 \%$ & 0,1516 \\
\hline
\end{tabular}

* Multiple choice of answers possible

Source: own study.

Study found that large enterprises and longer operating on the market significantly more often in acquiring knowledge EU funds benefited from external consultancy, information points, training and thematic conferences.

Table 4. Sources of knowledge acquisition and the duration of the company's activity

\begin{tabular}{l|ccccc}
\hline Sources of knowledge & $<1$ year & $1-5$ years & $5-10$ years & $>10$ years & $\mathrm{Chi}^{2}$ test \\
\hline \multirow{2}{*}{ Radio } & 4 & 0 & 2 & 6 & 0,0782 \\
& $44,44 \%$ & $0,00 \%$ & $9,09 \%$ & $13,04 \%$ & $\mathrm{p}=0,439$ \\
TV/Telewizja & 7 & 9 & 8 & 16 & 0,1795 \\
Websites & $77,78 \%$ & $39,13 \%$ & $36,36 \%$ & $34,78 \%$ & $\mathrm{p}=0,074$ \\
& 4 & 16 & 10 & 27 & 0,0030 \\
External consultancy & $44,44 \%$ & $69,57 \%$ & $45,45 \%$ & $58,70 \%$ & $\mathrm{p}=0,977$ \\
Information pairs & 0 & 3 & 3 & 23 & 0,3994 \\
& $0,00 \%$ & $13,04 \%$ & $13,64 \%$ & $50,00 \%$ & $\mathrm{p}=0,000$ \\
Training & 0 & 3 & 13 & 25 & 0,3963 \\
& $0,00 \%$ & $13,04 \%$ & $59,09 \%$ & $54,35 \%$ & $\mathrm{p}=0,000$ \\
Conferences & 0 & 8 & 16 & 24 & 0,2660 \\
& $0,00 \%$ & $34,78 \%$ & $72,73 \%$ & $52,17 \%$ & $\mathrm{p}=0,007$ \\
Other: leaflet / press & 0 & 3 & 3 & 16 & 0,2807 \\
& $0,00 \%$ & $13,04 \%$ & $13,64 \%$ & $34,78 \%$ & $\mathrm{p}=0,005$ \\
& 4 & 3 & 1 & 2 & 0,0169 \\
\hline
\end{tabular}

* Multiple choice of answers possible

Source: own study. 
According to the respondents, their company after using the funding gained better brand and product recognition 38\%, improved financial liquidity $33 \%$, increased its innovation and competitiveness $25 \%$. In the opinion of every fifth person examined, EU funds did not change anything in the company's operations.

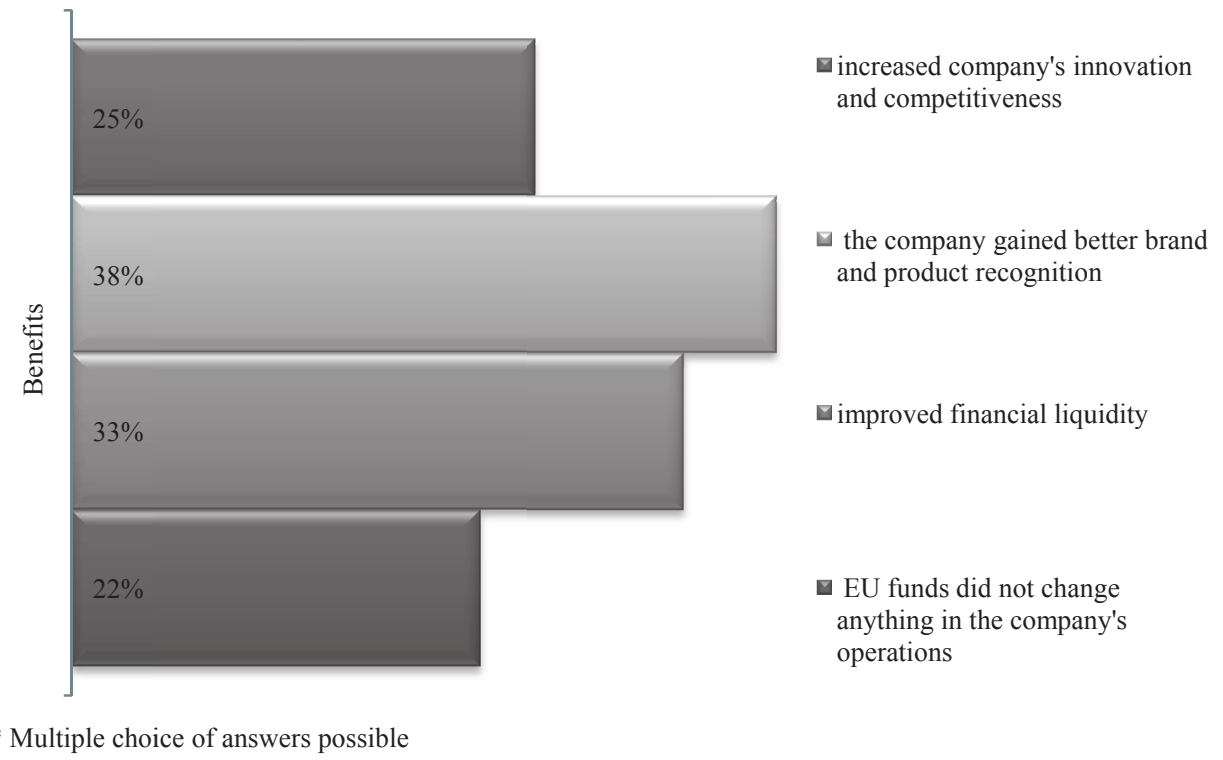

Fig. 7. Evaluation of the benefits of using EU funds in the opinion of respondents

Source: own study.

In the surveyed group, $73 \%$ confirmed that their company is planning to apply in the future for EU funding. A negative answer was given by $27 \%$ of respondents (Fig. 8).

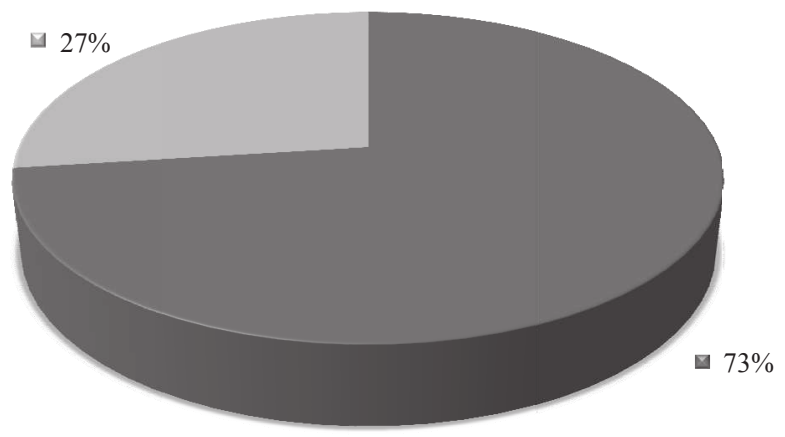

$\square$ Yes $\square$ No

Fig. 8. Application in the future for co-financing from EU funds

Source: own study. 
In innovative, well-managed enterprises, the principle of small and medium-sized enterprises is oriented towards entrepreneurship and competitiveness, which are characterized by forward-looking thinking and the perception of changes on the market and in the whole region as an opportunity for development (Strużycki, 2011). In the assumptions of the European Union's activity there is a principle of leveling the development of all its regions, in which SMEs have a special role to play in the area of regional development (Pach, Solińska, 2010). Dave Ulrich, Wayne Brockbank, Arthur K. Yeung and Dale G. Lake shared insights about improvement in SMES which could be made by HR management: They add value by ensuring that they deliver ideas, programs, and initiatives to their business which helps the business compete (Ulrich, Brockbank, Yeung, Lake, 1995).

In own research, in the opinion of $83 \%$ of respondents, EU funds help in the development of enterprises, including the development of human capital. Only $11 \%$ of the group expressed negative opinion. Therefore, $73 \%$ of the group confirmed that their company is planning to apply for EU funding in the future despite the fact that $43 \%$ of it is very difficult to receive EU funding. It was found that the respondents who obtained information about subsidies from the radio and the Internet significantly assessed more often that obtaining co-financing is very difficult. On the other hand, companies using external consultancy and conferences considerably more often believed that obtaining EU funds is not difficult. As the biggest obstacle to obtaining EU funds, the respondents indicated complex and lengthy procedures (69\%), which significantly discourages the submission of applications for co-financing from the European Union. A small amount of information $(52 \%)$ and problems were also mentioned as barriers with the completion of the application (23\%), a long period of considering the application (19\%). It was found that the low level of knowledge of owners and employees is a barrier to obtaining funding from the European Union.

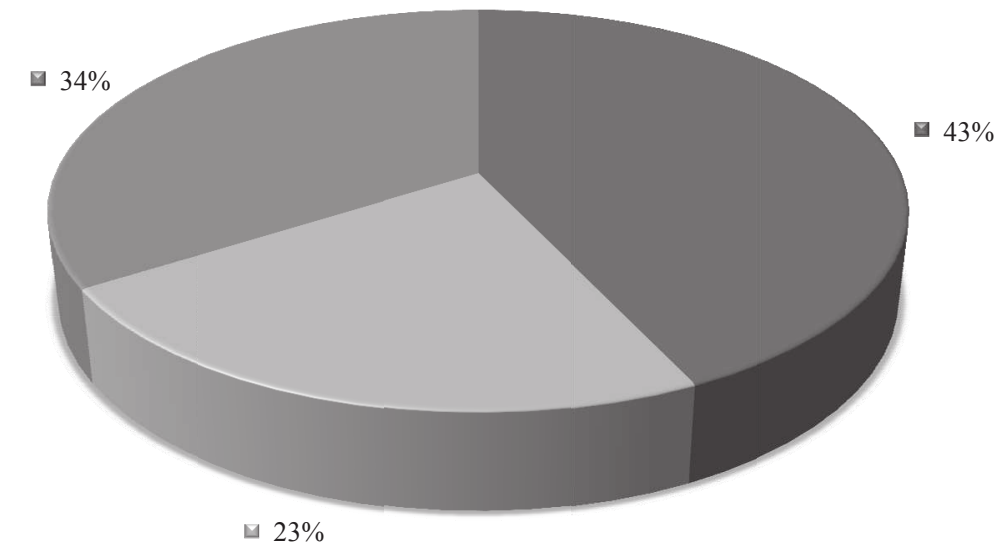

$\square$ it is very difficult to receive EU funding $\square$ it isn't very difficult to receive EU funding $\square$ it's hard to say

Fig. 9. Evaluation of applying for financial resources from the European Union in the opinion of respondents Source: own study. 


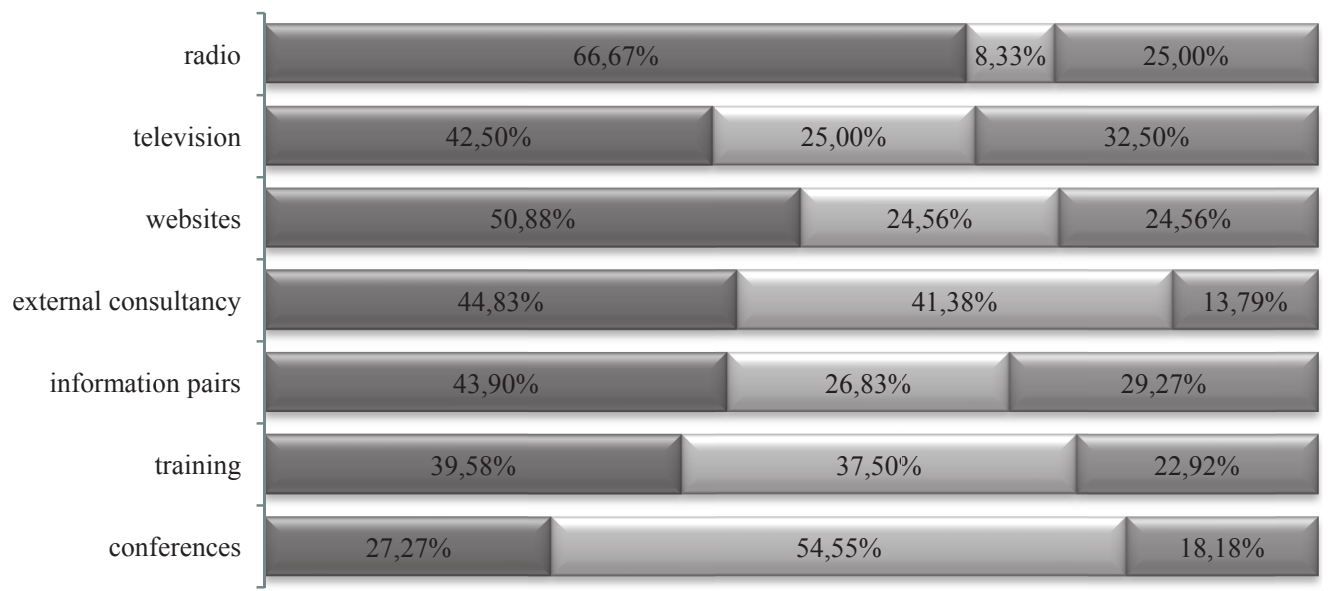

$\square$ it is very difficult to receive EU funding $\square$ it isn't very difficult to receive EU funding $\square$ it's hard to say

Fig. 10. Support for EU funds in the development of enterprises and the way of acquiring knowledge Source: own study.

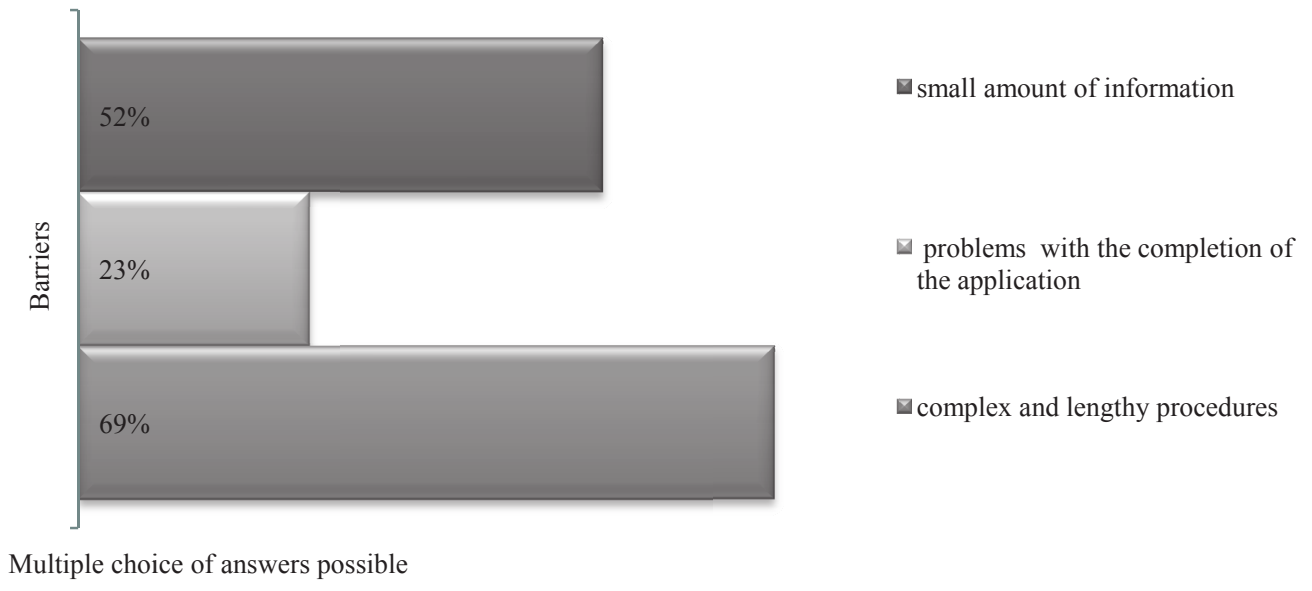

Fig. 11. Barriers in obtaining EU funds in the opinion of the respondents Source: own study.

\section{Summary}

European integration has significantly contributed to the development of small and medium-sized enterprises. Poland, wanting to join the community, had to carry out a number of political, legal and economic changes. The consequence of this decision could 
not be fully predicted, it was feared that Poland's accession to the Union would be disadvantageous, above all, for entrepreneurs from the SME sector. It is a group of enterprises that are most exposed to changes in the environment.

The results of the conducted research indicate clearly that the surveyed entrepreneurs in the majority, they assess Poland's membership in the Union very positively. The vast majority of them benefited from financial aid offered by the European Union - programs intended for small and medium-sized enterprises. Entrepreneurs evaluate the programs very positively and seeing the improvement of development and increase of competitiveness on the market decide to use in the future new programs that create opportunities, among others for better use of employees' potential. The respondents also gave an answer to the question about the biggest barriers in applying for funding, this information may help in the streamlining of the procedure granting co-financing. Entrepreneurs recognize the benefits of European integration. Although obtaining funds in the respondents' opinion is not easy, they state that the products of their brand are better recognized, companies also have the opportunity to innovate and better support in shaping and developing human capital.

Based on the above research results, it can be concluded that European integration has a positive effect on the development of small and medium enterprises in Poland in all areas of their activity. From year to year, the awareness of entrepreneurs in the SME sector is growing as to the need to invest in human capital as a strategic factor of modern enterprises enabling efficient functioning in the face of dynamically changing changes, and growing competition on global markets.

\section{Literature}

Danielak, W., Mierzwa, D., Bartczak, K. (2017). Małe i średnie przedsiębiorstwa w Polsce. Szanse i zagrożenia (Small and medium enterprises in Poland market opportunities and threats). EXANTE Publishing House, Wrocław.

Juchnowicz, M. (2013). Troska o satysfakcję pracowników - nowy paradygmat czy pragmatyzm? (Care for employee satisfaction - a new paradigm or a new pragmatism?). Zarzqdzanie Zasobami Ludzkimi, 3-4, 5160.

Kamińska, A. (2010). Programy pomocowe Unii Europejskiej jako źródło finansowania rozwoju i konkurencyjności sektora małych i średnich przedsiębiorstw (European Union assistance programs as a source of financing the development and competitiveness of the small and medium-sized enterprises sector). Barometr Regionalny, 2(20), 51-63.

Kaufmann, H., R., Tsangar, H., Vrontis, D. (2012). Innovativeness of European SMEs: Mission not yet accomplished. Economic Research-Ekonomska Istra živanja, 25(2), 333-359.

Król, A. (2016). Koncepcje zarządzania kapitałem ludzkim w aspekcie procesu globalizacji i kształtowania kultury organizacji (Concepts of human capital management in the aspect of the process of globalization and shaping the culture of the organization). Zarzqdzanie. Teoria i Praktyka, 18(4), 59-66.

Król, H., Ludwiczyński, A. (2008). Zarządzanie zasobami ludzkimi. Tworzenie kapitału ludzkiego organizacji (Human Resource Management). Creating the human capital of the organization. Wyd. Nauk. PWN, Warszawa.

Lewandowska, B. (2016). European Union support for the SME sector in Poland. University of Warmia and Mazury in Olsztyn Faculty of Economic Sciences, Olsztyn.

Mirończuk, J. (2012). Wpływ Europejskiego Funduszu Społecznego na sektor MSP w Polsce (Impact of the European Social Fund on the SME sector in Poland). Zarzqdzanie i Finanse, 10(1/3), 19-32.

Pach, J., Solińska, M. (2010). The problem of help for small and medium enterprises in Poland after the accession to the European Union. In: Z. Zioło, T. Rachwał (ed.), Entrepreneurship in the conditions of European integration, the Pedagogical University of Cracow, Cracow.

Report on the state of the sector of small and medium-sized enterprises in Poland (2017). Polish Agency for Enterprise Development, Warsaw. 
Schmelter, R., Mauer, R., Börsh, C., Brettel, M. (2012). Boosting corporate entrepreneurship through HRM practices; evidence from German SMEs. Human Resource Management, 49, 715-741.

Strużycki, M. (2011). Przedsiębiorstwo, region, rozwój (Enterprise, region, development). Difin, Warszawa.

Measure the most difficult measurable. Good practices in measuring human capital in enterprises, PARP 2015, Wydawnictwo Naukowe Instytutu Technologii Eksploatacji-PIB.

Human Resources Management Leader Competition. Downloaded 12/09/2018 from: https://www.ipiss.com.pl/ konkurs-lider..

Ulrich, D., Brockbank, W., Yeung, A.K., Lake, D.G. Human resource competencies: An empirical assessment. Downloaded 06/12/2018 from: http://onlinelibrary.wiley.com/doi/10.1002/hrm.3930340402/full.

Wielewska, I., Kacprzak, M., Król, A., Siedlecka, A. (2018). Human capital in the aspect of raising innovativeness in rural areas, International Scientific Days 2018, Slovak University of Agriculture in Nitra, Nitra.

\section{For citation:}

Kacprzak M., Król A., Radziszewska M. (2018). European Integration Influence on the Development of Human Capital of Small and Medium Enterprises in Poland. Problems of World Agriculture, 18(4), 236-249; DOI: 10.22630/PRS.2018.18.4.114 